\title{
CANDIKUNING VILLAGE MASTERPLAN BASED ON TOURISM
}

\author{
Ida Bagus Suryawan
}

Faculty of Tourism, Udayana University, Indonesia

Email: idabagussuryawan@unud.ac.id

\begin{tabular}{|c|c|}
\hline ARTICLE INFO & ABSTRACT \\
\hline $\begin{array}{l}\text { Received: } \\
\text { December, 26th } \\
2021 \\
\text { Revised: } \\
\text { January, 17th } \\
2022 \\
\text { Approved: } \\
\text { January, 18th } \\
2022\end{array}$ & $\begin{array}{l}\text { The authentic characteristic of a village becomes the main } \\
\text { tourism attraction that can be offered to tourists. Alternative } \\
\text { tourism products are needed that can provide impetus for } \\
\text { sustainable rural development and have management principles. } \\
\text { Candi Kuning Village, which is part of the National Tourism } \\
\text { Strategic Area, is one of the villages that is still able to survive in } \\
\text { carrying out tourism services during the Covid } 19 \text { pandemic. This } \\
\text { study aims to formulate a Master Plan as well as infrastructure } \\
\text { development programs and other strategic infrastructures that } \\
\text { are integrated between sectors, between spaces and between } \\
\text { activities in one village area. The method used in this study uses } \\
\text { a planning method consisting of a scoring method presented in } \\
\text { the competitor matrix, a qualitative method for formulating an } \\
\text { activity structure and SWOT. The results of the competitor matrix } \\
\text { analysis show that the main competitors are Lake Buyan, tourist } \\
\text { accommodation in the area, Agro Tourism and Culinary Tourism. } \\
\text { The planning of the activity center is designed to be divided into } \\
4 \text { activity centers. The activity development plan in Candi Kuning } \\
\text { Village consists of activities oriented to lake views, forest view } \\
\text { orientation activities, development of local products (culinary } \\
\text { and agro), utilization of community agricultural areas, } \\
\text { environmental-based attractions and artificial attractions. The } \\
\text { facilities developed are more for the appearance of the village, } \\
\text { especially at the village border and activity center. This master } \\
\text { plan is expected to strengthen the appearance of the village, } \\
\text { increase tourism networks, increase the variety of income and } \\
\text { self-motivation of the community in tourism services by local } \\
\text { organizations. }\end{array}$ \\
\hline KEYWORDS & urism Village, Masterplan, Pemaduserasian \\
\hline (c) (i) & $\begin{array}{l}\text { This work is licensed under a Creative Commons } \\
\text { Attribution-ShareAlike } 4.0 \text { International }\end{array}$ \\
\hline $\begin{array}{l}\text { How to cite: } \\
\text { E-ISSN: } \\
\text { Published by }\end{array}$ & $\begin{array}{l}\text { an. (2022). Candikuning Village Masterplar } \\
\text { hal Eduvest. Vol 2(1): } 81-88\end{array}$ \\
\hline
\end{tabular}




\section{INTRODUCTION}

Village areas are more often identified with areas outside urban areas where the dominant community activity is agrarian (Kelly, 2011). The development and development of rural areas generally prioritizes the utilization and optimization of village potentials to improve community welfare (Lange, Piorr, Siebert, \& Zasada, 2013). In an effort to develop the village, various themes were raised to promote the uniqueness of the village. One of the themes introduced is the theme of the tourist village. Rural areas with the theme of a tourist village generally take advantage of the distinctive character of the village, both from the aspect of agriculture, community culture, natural beauty and other elements in the village such as geological conditions (Murphy, Benckendorff, Moscardo, $\&$ Pearce, 2011). The development of the use of the tourism village theme as one of the village development options is increasingly being applied to a number of villages (Ghaderi \& Henderson, 2012). Many tourist village themes are applied to all village areas, many also develop this concept in a number of locations that tend to have the potential to be developed as tourism. In this context, of course, not all tourism village criteria are applied in rural areas. In this case, the term tourism village is only used as a brand / brand of tourism offerings to tourists.

The development of tourist villages should not only utilize most of the village area as tourism, but prioritize the extent to which tourism activities are inherent in people's daily lives and are able to make a dominant contribution to the welfare of the community (Lane, 1994). The many opportunities and economic involvement of the community in the tourism sector should be able to make an effective contribution to improving the quality of life of the community (Wearing \& McDonald, 2002). Economic opportunities for tourism attraction businesses, accommodation businesses, tourism businesses that support activities and other primary and secondary sector activities supporting tourism, have the opportunity to be carried out by the community by prioritizing the tourism theme (Stolarick, Denstedt, Donald, \& Spencer, 2010). In the development of tourism activities in the village, the application of ideal and global concepts is necessary and must be done to emphasize the commitment to good service and prioritize the welfare of the community (Rosentraub \& Joo, 2009). A number of global concepts that are widely demanded and applied to tourism actors are sustainable tourism development and the principle of excellent service (Liu, 2003). With this approach, tourism products made must prioritize the balance of tourism benefits against economic, environmental and cultural conditions that exist in the tourism environment. The principle of excellent service is put forward in the tourism sector because the basic principle of tourism is service so that good service is more identified as a good tourism product (Boyd, 2002). With the application of these ideal concepts, the preparation, packaging and sales of tourism products in tourist villages are expected to be able to provide optimal impetus for the development of tourist villages (Middleton \& Clarke, 2012).

Candi Kuning village, located in the Bedugul area, has a lot of tourism potential that has existed and developed for a long time. The existence of Lake Beratan in this area makes many tourism businesses appear while introducing the beauty of the lake and the temples in it. Besides the existence of a lake, in this village there are also unique agricultural activities of the residents who develop agriculture of vegetables and fruits. As a complement to tourism activities in the Bedugul area, many agro-tourism developments have sprung up and developed along with the development of tourism in this village. Candi Kuning Village is part of the Scope of the Region. During the COVID-19 pandemic in 2020 and 2021, tourism development and the number of tourist visits in 
Candi Kuning Village did not experience a sharp decline. Tourist visits are still high on holidays and holidays and more domestic tourists visit. Bedugul National Tourism Strategic and Surrounding Areas. There are 8 villages that are part of this area. Based on statistical data of tourist visits, three DTWs: Bedugul Botanical Gardens, Ulun Danu Beratan Temple, and Bedugul Tourism Objects always occupy the top 10 tourist visits in Bali. All of these DTWs are located in Candi Kuning Village. In tourism development, planning is needed to formulate strategic steps that must be taken to achieve the goals of tourism development carried out. This research was conducted so that the Master Plan as well as infrastructure development programs and other strategic infrastructures are integrated between sectors, regions and between levels of government, based on needs.

\section{RESEARCH METHOD}

This study uses a number of analytical tools in the context of formulating activities in program indications. A number of methods are used, namely the SCORING method to determine priority tourist attractions, the SWOT method to formulate strategies and the superimpose method to determine the tendency of tourism activity centers in existing conditions. The procedure for research activities is as follows:

a. Conducting data collection and preliminary studies of existing or available potential data to determine tourist objects that can be developed at the activity location.

b. Conduct field surveys to collect data that will be used as material in mapping potential.

c. Conduct an assessment through tabulation and analysis of the data collected using the established method.

d. Creating a Master Plan Document for Tourism-Based Rural Area Development includes :

1. Vision, Mission, Goals and Targets of Tourism-Based Rural Area Development

a) Candidate Location Area

b) Vision and Mission of Tourism-Based Rural Area Development

c) Objectives and Targets of Tourism-Based Rural Area Developmen

2. Tourism Village-Based Development Plan

a) Analysis of Tourism Elements for Tourism Village Development

b) Population, Employment and Socio-Cultural Analysis

c) Analysis of Rural Area Development Facilities and Infrastructure

d) Economic Analysis and Economic Development of Rural Areas

e) Analysis of Human Resource Needs for Rural Area Development

3. Strategy and Activity Plan for Development of Rural Areas Based on Tourism Villages.

\section{RESULT AND DISCUSSION}

\section{Conditions of Candi Kuning Village}

Bedugul is located in Tabanan Regency, 48 kilometers (30 miles) north of Denpasar city or 20 kilometers (12 miles) south of Singaraja. In this area there are three crater lakes, namely Lake Bratan, Lake Buyan, and Lake Tamblingan. Bedugul is taken from the two words "Bedug" because of the existence of Muslim community groups around Bedugul and "Kul" from Kul-kul which is a traditional communication tool for 


\section{Ida Bagus Suryawan}

Balinese people whose functions are almost the same. as a stick. The merging of these two words then made the name of this area called Bedugul. Another historical story is the origin of the name Bedugul, namely in ancient times there was a king who was bathing in Lake Beratan and was accidentally seen by the local people, while they said the king's bedogol was seen. Those are some versions of naming Bedugul tourist attractions. Lake Beratan there is a temple called Pura Ulun Danu. In the front yard of the temple, just to the left of Ulun Danu Beratan, there are sarcophagi and stone boards, which were examined from the megalithic era, around 500 years BC. In the expulsion of the Chronicle of Mengwi, he explains that I Gusti Agung Putu, who was the founder of the Mengwi kingdom, built a temple on the shores of Lake Beratan, before he founded Pura Taman Ayun. In Lontar Babad Mengwi it is not stated exactly when he founded the Ulun Danu Beratan Temple, but what is found in the expulsion of the Babad Mengwi is the establishment of Taman Ayun Temple, whose ceremony was held at Anggara Kliwon Medangsia in Saka Sad Bhuta Yaksa Dewa namely Saka in 1556 or 1634 AD.

Candikuning Village is one of 12 villages in the Baturiti District, located approximately $30 \mathrm{~km}$ to the north from the center of Tabanan City. Candikuning Village has an area of 268 hectares with 43.74 hectares of rice fields and 35.09 hectares of rainfed areas. Dry land consists of farmland with an area of $125.60 \mathrm{Ha}$ and Settlement $50.56 \mathrm{Ha}$ which has the following boundaries:

- To the north : Pancesari Village

- East : Lake Beratan

- South : Baturiti Desa Village

- West : Bangli Village

Judging from the geographical conditions, the Candikuning Village area is land (High) with a height of approximately 20 meters above sea level. The air temperature ranges from 28 degrees Celsius to 32 degrees Celsius with an average rainfall of 1,100 $\mathrm{mm} /$ year. To optimize services to the community, the Candikuning Village area is divided into 6 Banjar Dinas, namely:

1. Banjar Dinas Kembang Merta

2. Banjar Dinas Candikuning I

3. Banjar Dinas Candikuning II

4. Banjar Dinas Bukit Catu

5. Banjar Dinas Pemuteran

6. Banjar Dinas Batusesa

Based on the results of the 2021 survey, it was found that there were 19 Tourist Attraction Providers, 25 tourist accommodations and 63 restaurants and food stalls. Based on Regional Regulation Number 12 of 2011 concerning the RTRW of Tabanan Regency, Candi Kuning Village is part of the Candi Kuning Area Development Center. The spatial pattern determined according to the RTRW Regional Regulation is Lake and its borders, Protected Forest, Nature Reserve, Buyan Tablingan TWA, KDTWK, Settlement, Plantation. A number of stipulations on the functions of the area that are included in the Candi Kuning Village area, namely: Bedugul Tourism Effective Area, World Cultural Heritage Area (Catur Angga Batukau), Batukau Protected Forest, Batukau Nature Reserve, Buan Tamlingan Nature Park, Lake Beratan Area and its surroundings

\section{Tourism Vision and Mission}

Formulation of the vision and mission of tourism development using SWOT analysis (Anggraeni \& Rasto, 2016). In the elaboration of internal and external factors, it is found that aspects of strength include: Diverse communities, Art Organizations, Choice of tourism products, Iconic DTW. Aspects of weakness include: No concept of tourism, Congestion, Area Utilities, Security. Aspects of Opportunities include: Special attraction 
opportunities, Accessibility, Community involvement, Annual events. Threat Aspects include: Transfer of land use, Conflict of interest, Competition of business actors, Competition of DTW. Based on the results of the calculation of weights and scores on internal and external aspects in Candi Kuning Village as tourism, the results show that the position of Candi Kuning Village is in an aggressive position. With this position, it is determined that in the future, Candi Kuning Village must take advantage of existing strengths by prioritizing existing opportunities.

Referring to the consideration of the SWOT analysis, the vision of tourism development in Candi Kuning Village is set, namely: An Advanced and Independent Village based on People's Economy. The vision sentence is determined by considering a number of aspects of the internal and external conditions of Candi Kuning Village and the position in the SWOT matrix. With this vision, a number of tourism development visions have been set, namely:

- Development of village-based tourist attractions

- Management of tourism businesses by the community

- Excellent organizational development

- A committed tourism network

\section{Development Analysis}

The development analysis is used to formulate a number of priority activities that will be implemented in Candi Kuning Village. In the analysis of tourism development, a number of analytical tools are used, namely: competitor matrix, activity structure analysis, and thematic determination of priority areas (Presenza \& Cipollina, 2010) (Ayhan, Taşl1, Özkök, \& Tatl1, 2020). Based on the analysis of the competitor matrix, the highest competitors in quadrant 1 are the views of the Bedugul area in order 3, the Bedugul botanical garden, Mertasari traditional market and the lake in order 1. In quadrant 1, existing competitors will face this tourism product which has high internal and external conditions. Meanwhile, in the 2nd quadrant, the tourist attraction of Lake Buyan and Tamblingan is in the 2nd order, culinary tourism is in the 4th order. In the 3rd quadrant the existing tourism products are agro tourism and agro products which are in the 2nd order and tourist accommodation in the 3rd order. In the 4th quadrant, there is artificial tourism which is the 3 rd order.

Analysis of the structure of activities is carried out by considering aspects of tourism business agglomeration, the level of interest (attraction) of tourist visits and accessibility. Based on the results of the super imposse analysis, 4 activity centers were established in Candi Kuning Village, namely:

1. Activity center 1 is located around DTW Bloom and its surroundings. At this activity center a number of things were developed, namely: tourist attractions, development of agro-tourism and tourist accommodation, facilities supporting tourism activities

2. Activity center 2 is on the border with Buleleng Regency. At this activity center, strawberry agro-tourism, tourism accommodation with views of agriculture and lakes, tourism support facilities and public facilities will be developed.

3. Activity center 3 is around Mertasari market. At this activity center, facilities and botanical gardens are developed as tourist attractions, trade and culinary trade facilities to support activities and public facilities to support tourism activities.

4. Activity center 4 is located around the edge of the lake. At this activity center, facilities and tourist attractions to support Lake Beratan are developed, activities are developed along the lake on the side of the provincial road, and the provision of public facilities to strengthen tourism activities.Considering the structure of 


\section{Ida Bagus Suryawan}

tourism activities in Candi Kuning Village, in the future it is necessary to consider the development of tourism activities that refer to the potential and developments that exist in a number of areas. The thematic development of tourism activities that will be developed are:

- Private accommodation center with lake view. The development of this activity is in Banjar Kembangmerta which is undergoing the development of tourist accommodation with the theme of Glamping and villas

- Center for culinary activities developed around the Lake Beratan DTW area. Along the road corridor, it is necessary to develop and offer culinary tourism activities

- Center for creative tourism activities around Blooms. In this area with views of Denpasar City and its lower area, it is interesting to develop tourism activities based on natural scenery

- Development of a center for socio-cultural life developed in the Batusesa and Pemuteran areas. In this banjar area, the development of a typical Balinese area can be developed more intensely.

\section{Strategy and Action Plan}

Formulating strategies and action plans refers to the concept of Michael Porter (1985) which describes an internally consistent view of the future. Scenarios are part of strategic planning that deals with tools and technologies to manage future uncertainty. Scenario planning refers to the development of tourism activities at the site. There are at least 6 cycles of developing tourism activities in Candi Kuning Village, namely:

1. Lake view orientation

2. Forest and highland views

3. Local products (agricultural and culinary)

4. Utilization of residents' agricultural areas, development of environment-based accommodation

5. Development of creativity-based artificial tourist attractions.

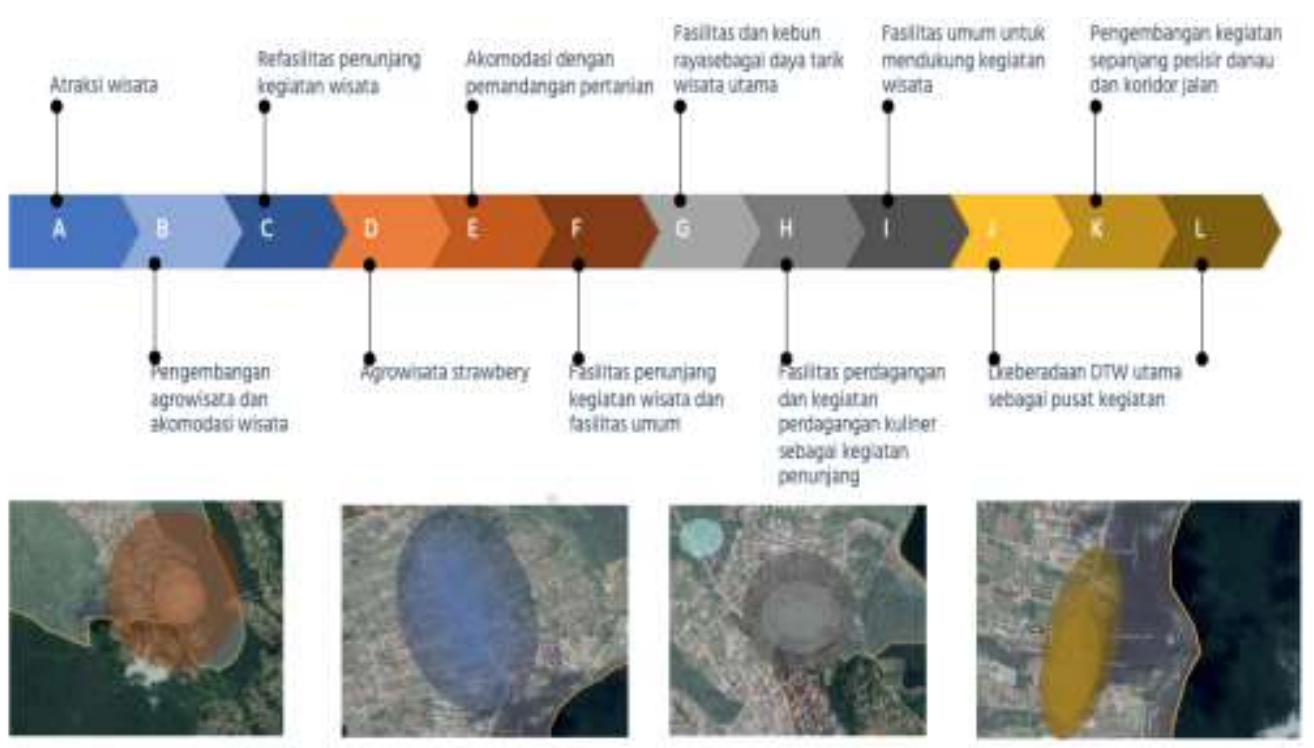


To market tourism products to be better in the future, a canvas business model is planned. In this business model planning, a series of directions are described, namely: the key stakeholders consist of; business actor tourist. The key activities developed are; tourism activities, artistic activities, agricultural activities, trading activities. The key resources used are: agriculture, tourism, social culture. There are several ways to connect with customers, namely: tour packages, loyalty and events. The marketing channels made consist of: direct sales, tour travel, and online marketing.

\section{CONCLUSION}

The magnitude of the potential of tourism resources in Candi Kuning Village is a challenge in future utilization and management. The durability of the tourism market in Candi Kuning Village has been tested during the pandemic. During the period of 2020 and 2021, the decline in tourist arrivals is still in a good condition where domestic tourist visits remain high in this area. The development of the village development vision and the thematic determination of tourism activities are expected to be able to spread tourism activities to a number of areas in Candi Kuning Village. With the determination of a number of areas with certain themes, it provides new challenges for the village to synergize tourism activities with the community's economy.

\section{REFERENCES}

Anggraeni, Rini, \& Rasto, Rasto. (2016). Job Satisfaction and Organizational Commitment as Determinants of Teacher Performance. 2016 Global Conference on Business, Management and Entrepreneurship, 525-529. Atlantis Press.

Ayhan, Çiğdem Kaptan, Taşl1, Tülay Cengiz, Özkök, Ferah, \& Tatl1, Hasan. (2020). Land use suitability analysis of rural tourism activities: Yenice, Turkey. Tourism Management, 76, 103949.

Boyd, Stephen. (2002). Cultural and heritage tourism in Canada: Opportunities, principles and challenges. Tourism and Hospitality Research, 3(3), 211-233.

Ghaderi, Zahed, \& Henderson, Joan C. (2012). Sustainable rural tourism in Iran: A perspective from Hawraman Village. Tourism Management Perspectives, 2, 47-54.

Kelly, Philip F. (2011). Migration, agrarian transition, and rural change in Southeast Asia: Introduction. Critical Asian Studies, 43(4), 479-506.

Lane, Bernard. (1994). What is rural tourism? Journal of Sustainable Tourism, 2(1-2), 7 21.

Lange, Andrej, Piorr, Annette, Siebert, Rosemarie, \& Zasada, Ingo. (2013). Spatial differentiation of farm diversification: How rural attractiveness and vicinity to cities determine farm households' response to the CAP. Land Use Policy, 31, 136-144.

Liu, Zhenhua. (2003). Sustainable tourism development: A critique. Journal of Sustainable Tourism, 11(6), 459-475.

Middleton, Victor T. C., \& Clarke, Jackie R. (2012). Marketing in travel and tourism. Routledge.

Murphy, Laurie, Benckendorff, Pierre, Moscardo, Gianna, \& Pearce, Philip L. (2011). Tourist shopping villages: Forms and functions (Vol. 22). Routledge.

Presenza, Angelo, \& Cipollina, Maria. (2010). Analysing tourism stakeholders networks. Tourism Review.

Rosentraub, Mark S., \& Joo, Mijin. (2009). Tourism and economic development: Which investments produce gains for regions? Tourism Management, 30(5), 759-770. 


\section{Ida Bagus Suryawan}

Stolarick, Kevin M., Denstedt, Mark, Donald, Betsy, \& Spencer, Gregory M. (2010). Creativity, tourism and economic development in a rural context: The case of Prince Edward County. Journal of Rural and Community Development, 5(1).

Wearing, Stephen, \& McDonald, Matthew. (2002). The development of communitybased tourism: Re-thinking the relationship between tour operators and development agents as intermediaries in rural and isolated area communities. Journal of Sustainable Tourism, 10(3), 191-206. 